\title{
Phenotypic and functional characterization of cytokine-induced killer cells derived from preterm and term infant cord blood
}

\author{
QIAN ZHANG ${ }^{1}$, LILI WANG $^{1}$, CHENGHAN LUO $^{1}$, ZANYANG SHI $^{1}$, XINRU CHENG $^{1}$, \\ $\mathrm{ZHEN} \mathrm{ZHANG}^{2,3}$, YI YANG ${ }^{4}$ and $\mathrm{YI} \mathrm{ZHANG}^{2,3}$ \\ ${ }^{1}$ Department of Neonatology, ${ }^{2}$ Biotherapy Center and ${ }^{3}$ Department of Oncology, The First Affiliated Hospital \\ of Zhengzhou University, Zhengzhou, Henan 450052; ${ }^{4}$ Newborn Disease Key Laboratory of the Ministry of Health, \\ The Children's Hospital Affiliated to Fudan University, Shanghai 201102, P.R. China
}

Received May 30, 2014; Accepted July 24, 2014

DOI: $10.3892 /$ or.2014.3457

\begin{abstract}
Cord blood has gradually become an important source for hematopoietic stem cell transplantation (HSCT) in the human, particularly in pediatric patients. Adoptive cellular immunotherapy of patients with hematologic malignancies after umbilical cord blood transplant is crucial. Cytokine-induced killer (CIK) cells derived from cord blood are a new type of antitumor immune effector cells in tumor prevention and treatment and have increasingly attracted the attention of researchers. On the other hand, it has been suggested that preterm infant cord blood retains an early differentiation phenotype suitable for immunotherapy. Therefore, we determined the phenotypic and functional characterization of CIK cells derived from preterm infant cord blood (PCBCIK) compared with CIK cells from term infant cord blood (TCB-CIK). Twenty cord blood samples were collected and classified into two groups based on gestational age. Cord blood mononuclear cells (CBMCs) were isolated, cultured and induced to CIK cells in vitro. We used flow cytometry to detect cell surface markers, FlowJo software to analyze the proliferation profile and intracellular staining to test the secretion of cytokines. Finally, we evaluated the antitumor activity of CIK cells against K562 in vitro. Compared with TCB-CIK, PCB-CIK cells demonstrated faster proliferation and higher expression of activated cell surface markers. The secretion of IL-10 was lower in PCB-CIK cells while the expression of perforin and CD107a had no significant difference between the two cell groups. PCB-CIK cells exhibited a high proliferation
\end{abstract}

Correspondence to: Dr Qian Zhang, Department of Neonatology, The First Affiliated Hospital of Zhengzhou University, Zhengzhou, Henan 450052, P.R. China

E-mail: jsbwnmm@126.com

Dr Yi Zhang, Biotherapy Center, The First Affiliated Hospital of Zhengzhou University, Zhengzhou, Henan 450052, P.R. China

E-mail: yizhang@zzu.edu.cn

Key words: cytokine induced-killer cells, preterm infant, term infant, cord blood, adoptive cellular immunotherapy rate while the cytotoxic activity had no difference between the PCB-CIK and TCB-CIK cells. Hence preterm infant cord blood may be a potential source for immunotherapy.

\section{Introduction}

Umbilical cord blood has gradually become an important source for hematopoietic stem cell transplantation (HSCT) in the human (particularly in pediatric patients) and has been applied in the radical treatment of hematologic malignancies, due to its richness in $\mathrm{CD}_{3} 4^{+}$cells, higher transplant survival rate, lower risk of graft-versus-host disease (GVHD) and convenient collection (1). Adoptive cell immunotherapy (AIT) of patients with hematologic malignancies after umbilical cord blood transplant has become a research hotspot in recent years, and is important to improve the long-term survival of children with hematologic malignancies after umbilical cord blood transplant. In recent years, cytokine-induced killer (CIK) cells as a new type of antitumor immune cells in tumor prevention and treatment have increasingly attracted the attention of researchers.

AIT involves the transfer into patients of immune cells that have been expanded and activated ex vivo to eliminate cancer cells. This approach has become an important and effective method of cancer therapy (2). The main limitation preventing the successful clinical translation of AIT strategies is the obtainment of sufficient numbers of antitumor immune effector cells and their persistence in vivo (3). In recent years, the application of CIK cells has evolved into an extensive clinical research topic. CIK cells exhibit a higher proliferation rate and cytotoxicity in contrast with lymphokine-activated killer (LAK) cells and tumor infiltrating lymphocytes (TILs) (4).

CIK cells are obtained ex vivo by stimulating mononuclear cells (MNCs) with interferon- $\gamma$ (IFN- $\gamma$ ), interleukin-2 (IL-2) and an anti-CD3 monoclonal antibody for a few weeks as initially described by Schmidt-Wolf et al (5). Bulk CIK cells can be described as a heterogeneous population consisting of a majority of cells with a $\mathrm{CD}{ }^{+} \mathrm{CD}^{2} 6^{+}$phenotype (NKT cells) and a minor fraction of cells with a CD3-CD56 ${ }^{+}$phenotype (NK cells) and a $\mathrm{CD}^{+} \mathrm{CD} 56^{-}$phenotype (CD3 ${ }^{+} \mathrm{T}$ lymphocytes). The major effector cells are the $\mathrm{CD}^{+}{ }^{+} \mathrm{CD} 56^{+}$subset, termed a mixed T-NK phenotype and with major histocompatibility 
complex (MHC)-unrestricted cytolytic activities against tumor cells (6). CIK cells derived from peripheral blood (PB) have demonstrated an effective antitumor potential both in vitro and in vivo against solid tumors, hematological malignancies and virus-associated tumors (7-10). In recent years, a large amount of clinical studies have proven the effectiveness, safety and feasibility of CIK cells derived from PB $(11,12)$. However, PB is not always a viable cell source, particularly for allogeneic transplantation, due to the risk of acute GVHD (13). Moreover, the application of autologous CIK cells is limited due to the short survival period in vivo and the lower anti-apoptotic ability. Furthermore, older patients who have poor health cannot tolerate repeated bleeding and cell infusion. Umbilical cord blood has become a viable alternative source for transplantation due to its several advantages over PB, such as widespread availability, absence of donor and attrition, low risk of transmissible infectious diseases in the cells, decreased GVHD and more importantly, a higher frequency of immune accessory and effector cell precursors such as dendritic cell precursors, natural killer cell precursors and T-cell precursors (14). Hence, they have attracted extensive concern.

CIK cells derived from cord blood (CB-CIK) have been used in the clinic, and the safety, feasibility and availability have been proven in clinical studies (15). However, CIK cells used in preclinical and clinical studies are mainly derived from term infant cord blood, from which an adequate and high quantity of cells can be harvested for transfer. In recent years, the birth rate of preterm infants has increased significantly. A retrospective study was conducted on neonates born in 2005 in the maternity departments of 72 urban hospitals from 22 provinces in China (16). A total of 45,722 infants born between January 1, 2005 and December 31, 2005 were enrolled. Preterm births accounted for $8.1 \%$, and the incidence of very low birth weight infants was $0.7 \%$. Whether the phenotypic and functional characterization of CIK cells derived from preterm and term infant cord blood is consistent remains unclear. Moreover, the biological characterization of CIK cells obtained from preterm infant cord blood has rarely been reported. In the present study, we cultured CIK cells from preterm and term infant cord blood and analyzed the proliferation, phenotype, the secretion of cytokines and the cytotoxicity in the two cell groups.

\section{Materials and methods}

Human materials. Between June 2013 and December 2013, umbilical cord blood was obtained from 20 Cesarean deliveries at the Obstetrical Department of the First Affiliated Hospital of Zhengzhou University (Zhengzhou, China). The samples were classified into two groups according to gestational age (GA): preterm infant $(n=10, G A<37$ weeks and mean $34+1$ weeks+day) and term infant $(n=10, G A \geq 37$ weeks and mean $38+4$ weeks+day). The maternal age range was 18 to 35 years. During pregnancy, there was no presence of hematological system diseases, communicable diseases and premature rupture of membranes. This study was conducted with written informed consent obtained from the parturients and was approved by the Ethics Committee of the First Affiliated Hospital of Zhengzhou University.
Isolation and culture of CIK cells. CIK cells were generated as previously described (15). In brief, cord blood MNCs (CBMCs) were separated by Ficoll density gradient (Tianjin, China) centrifugation, washed and resuspended at $2 \times 10^{6}$ cells $/ \mathrm{ml}$ in RPMI-1640 (Gibco, USA), consisting of 10\% fetal calf serum (FCS; Sigma, USA), $100 \mathrm{U} / \mathrm{ml}$ penicillin and $100 \mathrm{U} / \mathrm{ml}$ streptomycin (both from Shijiazhuang, China). Recombinant human IFN- $\gamma(1,000 \mathrm{U} / \mathrm{ml})$ (Beijing, China) was added on day 0 . After $24 \mathrm{~h}$ of incubation, $1,000 \mathrm{U} / \mathrm{ml}$ recombinant human IL-2 (Beijing, China) and $25 \mathrm{ng} / \mathrm{ml}$ anti-CD3 monoclonal antibody (Boehringer, Mannheim, Germany) were added. Cells were incubated at $37^{\circ} \mathrm{C}$ in a humidified atmosphere of $5 \% \mathrm{CO}_{2}$ and subcultured every 2-3 days in fresh complete medium and IL-2 at $2 \times 10^{6}$ cells $/ \mathrm{ml}$.

K562 cell line. The K562 cell line (a chronic myeloid leukemia cell line; Shanghai, China) was stored at $-80^{\circ} \mathrm{C}$. The recovered cells were maintained in RPMI-1640 medium supplemented with $10 \%$ FCS, $100 \mathrm{U} / \mathrm{ml}$ penicillin and $100 \mathrm{U} / \mathrm{ml}$ streptomycin. Fresh complete medium was replenished every 2 days.

Proliferation assay. CIK cells derived from preterm and term infant cord blood were collected on day 5 , washed and resuspended in RPMI-1640 at a final concentration of $1 \times 10^{6} \mathrm{cells} / \mathrm{ml}$. In dark conditions, $5 \mathrm{mmol} / 1$ 5,6-carboxyfluorescein succinimidyl ester (CFSE; Invitrogen) was added, and cells were labeled for $10 \mathrm{~min}$ at $37^{\circ} \mathrm{C}$. Staining was then stopped with $200 \mu \mathrm{l} \mathrm{FCS}$ for $8 \mathrm{~min}$ at $4^{\circ} \mathrm{C}$. CIK cells were washed twice with phosphate-buffered saline (PBS). A total number of $1 \times 10^{5}$ labeled CIK cells were detected by FACSCanto II flow cytometry (BD, USA), while the other CIK cells were cultured on 24-well plates. IL-2 and fresh complete medium were replenished every 2-3 days. A volume of $1 \times 10^{5} \mathrm{CIK}$ cells was collected daily from day 5 to 10 , and the proliferation index (PI) of the CIK cells was determined using FlowJo software (BD).

Flow cytometry. The immunophenotype of CIK cells derived from preterm and term infant cord blood was monitored by flow cytometry at day 0,7 and 14 using the following antihuman antibodies: CD3-PE-Cy7, CD4-APC-Cy7, CD8-PerCP and CD56-PE. The activated or inhibitory cell surface markers of CIK cells derived from preterm and term infant cord blood were monitored at day 0 and 14 using the following anti-human antibodies: CD27-FITC, CD28-APC and PD-1-PE. The antibodies and isotype-matched monoclonal antibodies were purchased from BD Biosciences (BD). A total of $5 \times 10^{5}$ cells was collected and washed twice, and then the supernatant was discarded. A volume of $10 \mu \mathrm{l}$ appropriate monoclonal antibody was added and then the cells were incubated for $30 \mathrm{~min}$ at $37^{\circ} \mathrm{C}$. After incubation, the cells were washed twice and resuspended in $500 \mu \mathrm{l}$ PBS. Data acquisition was performed by flow cytometry and analyzed using Diva software (both from BD). When detecting the immunophenotype, we gated the population of $\mathrm{CD}^{+} \mathrm{T}$ cells, and when detecting the expression of $\mathrm{CD} 27, \mathrm{CD} 28$ and PD-1, we gated the population of $\mathrm{CD}^{+} \mathrm{CD} 8^{+}$ or $\mathrm{CD}^{+}{ }^{+} \mathrm{CD} 4^{+} \mathrm{T}$ cells.

Determination of cytokine secretion. On day 12 , CIK cells were adjusted to a final concentration of $2 \times 10^{6}$ cells $/ \mathrm{ml}$ and cultured 
Table I. Phenotypic characteristics of the cells from preterm and term infant cord blood.

\begin{tabular}{|c|c|c|c|c|c|c|}
\hline \multirow[b]{2}{*}{ Days } & \multicolumn{3}{|c|}{ Preterm infant } & \multicolumn{3}{|c|}{ Term infant } \\
\hline & $\mathrm{CD}^{+}{ }^{+} \mathrm{CD} 56^{+}$ & $\mathrm{CD}^{+}{ }^{+} \mathrm{CD} 4^{+}$ & $\mathrm{CD}^{+}{ }^{+} \mathrm{CD}^{+}$ & $\mathrm{CD}^{+}{ }^{+} \mathrm{CD} 56^{+}$ & $\mathrm{CD}^{+}{ }^{+} \mathrm{CD}^{+}$ & $\mathrm{CD}^{+}{ }^{+} \mathrm{CD} 8^{+}$ \\
\hline 0 & $0.2 \pm 0.2$ & $71.1 \pm 9.3$ & $26.9 \pm 9.0$ & $0.4 \pm 0.4$ & $72.1 \pm 7.0$ & $26.2 \pm 7.4$ \\
\hline 7 & $11.9 \pm 4.2^{\mathrm{a}}$ & $32.9 \pm 9.9^{\mathrm{a}}$ & $67.7 \pm 9.9$ & $8.1 \pm 3.5$ & $43.1 \pm 9.4$ & $59.9 \pm 10.0$ \\
\hline 14 & $27.2 \pm 11.0^{\mathrm{a}}$ & $16.9 \pm 7.7^{\mathrm{a}}$ & $84.1 \pm 7.1^{\mathrm{a}}$ & $16.7 \pm 7.1$ & $23.8 \pm 5.5$ & $78.0 \pm 5.1$ \\
\hline
\end{tabular}

Comparison among two groups ( $\left.{ }^{\mathrm{a}} \mathrm{P}<0.05\right)$.

in RPMI-1640 medium consisting of 1,000 U/ml IL-2. After $48 \mathrm{~h}$, the supernatants were collected and stored at $-80^{\circ} \mathrm{C}$. To detect the secretion of IL-10, IFN- $\gamma$ and tumor necrosis factor (TNF)- $\alpha$, an enzyme-linked immunosorbent assay (ELISA) development with matched antibody pairs (BioLegend, USA) was performed according to the manufacturer's instructions.

Cytotoxicity assay. We selected the logarithmic phase of K562 cells as the target cells in this cytotoxicity assay. CIK and K562 cells were co-cultured at an effector-target ratio of 20:1 with $5 \mu \mathrm{g} / \mathrm{ml} 1 \mathrm{X}$ Brefeldin A (BFA; BioLegend) for $5 \mathrm{~h}$. For the positive control, CIK cells $\left(2 \times 10^{6}\right)$ were stimulated $5 \mathrm{~h}$ with $1 \mathrm{mg} / \mathrm{ml}$ phorbol myristate acetate (PMA), $1 \mathrm{mg} / \mathrm{ml}$ ionomycin (both from Sigma) and $2.5 \mu \mathrm{g} / \mathrm{ml}$ 1X BFA. Cells were collect and resuspended in PBS, mixed with $10 \mu$ l of CD107a-FITC (BD), CD3-PE-Cy7 and CD56-PE. Incubation was carried out for $30 \mathrm{~min}$ at $37^{\circ} \mathrm{C}$ and then cells were suspended in PBS. We also detected the expression of granzyme $\mathrm{B}$ and perforin in the two groups. CIK cells $\left(2 \times 10^{6}\right)$ were stimulated for $5 \mathrm{~h}$ with $1 \mathrm{mg} / \mathrm{ml} \mathrm{PMA}, 1 \mathrm{mg} / \mathrm{ml}$ ionomycin and $2.5 \mu \mathrm{g} / \mathrm{ml} 1$ X BFA. After $5 \mathrm{~h}$ of incubation, CD3-PE-Cy7, CD4-APC-Cy7 and CD8-PerCP were added, and then the cells were incubated for $15 \mathrm{~min}$ at $37^{\circ} \mathrm{C}$. We then sequentially added $4 \%$ paraformaldehyde (Tianjin, China) and permeabilization wash buffer (1X; Caltag, USA) to the system. The cells were washed twice with permeabilization wash buffer (1X) and mixed with granzyme B-PE and perforin-FITC. The expression levels of CD107a, granzyme B and perforin were detected by flow cytometry. The antibodies and isotype-matched monoclonal antibodies were purchased from BD Biosciences.

Statistical analysis. All data are presented as means \pm SD. SPSS 16.0 (SPSS Inc., Chicago, IL, USA) was used for statistical analysis, and GraphPad Prism version 5.0 (GraphPad Software Inc., USA) was used for data plotting. Statistical differences between the groups were analyzed using t-test. A P-value of $<0.05$ was considered to indicate a statistically significant result.

\section{Results}

Cell proliferation of $\mathrm{CIK}$ cells. To detect the proliferation of PCB-CIK and TCB-CIK cells, we used the CFSE assay to examine the change in the proliferation of the two groups. The PI of PCB-CIK and TCB-CIK cells had no difference on days 5 and 6 , yet PCB-CIK showed a significantly elevated

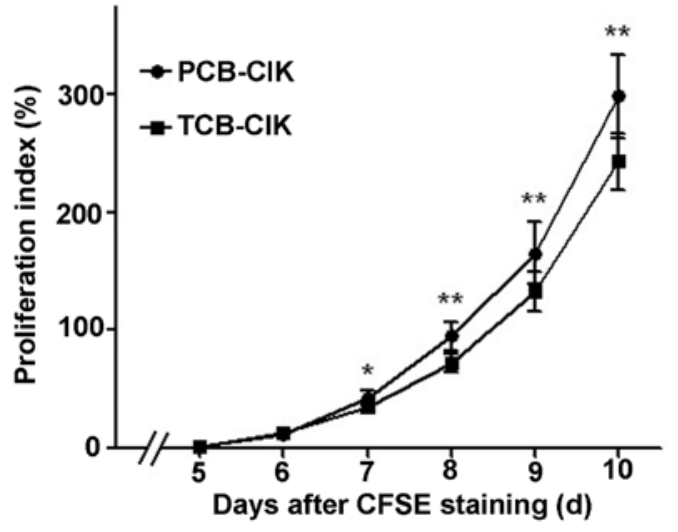

Figure 1. Expansion of CIK cells derived from preterm and term infant cord blood (PCB-CIK and TCB-CIK) in vitro. Proliferation index (PI) data are presented as means $\pm \mathrm{SD}\left({ }^{*} \mathrm{P}<0.05,{ }^{* *} \mathrm{P}<0.01\right)$. CIK, cytokine-induced killer; $\mathrm{PCB}$, preterm infant cord blood; TCB, term infant cord blood; CFSE, 5,6-carboxyfluorescein succinimidyl ester.

PI compared with TCB-CIK on days 8,9 and $10(95.0 \pm 11.8$ vs. $72.3 \pm 7.2 \%, 165.5 \pm 25.8$ vs. $132.6 \pm 17.2 \%, 298.4 \pm 35.2$ vs. $243.0 \pm 23.7 \%$, respectively, all $\mathrm{P}<0.01$, Fig. 1).

Phenotype of CIK cells. MNCs derived from preterm and term infant cord blood (P-CBMCs and T-CBMCs) were isolated and induced to CIK cells. We detected the phenotype by flow cytometry at days 0,7 and 14 (Fig. 2a, c and e). Along with an increase in the culture days, the proportion of $\mathrm{CD} 3{ }^{-} \mathrm{CD} 56^{+}$ (NK) cells gradually increased, and the proportion of NK cells was higher in the group of preterm infants $(\mathrm{P}<0.05$, Table I). The percentage of $\mathrm{CD}^{+}{ }^{+} \mathrm{CD} 56^{+} \mathrm{T}$ (NKT) cells was higher in the PCB-CIK than that in the TCB-CIK cells on days 7 and $14(\mathrm{P}<0.05$, Fig. $2 \mathrm{~b})$. The percentage of $\mathrm{CD}^{+} \mathrm{CD}^{+} \mathrm{T}$ cells was lower in the PCB-CIK than that in the TCB-CIK cells on days 7 and 14 ( $\mathrm{P}<0.05$, Fig. 2d). Yet, the percentages of NKT and $\mathrm{CD}^{+}{ }^{+} \mathrm{CD}^{+} \mathrm{T}$ cells had no difference in the MNCs derived from preterm and term infants on day $0(\mathrm{P}>0.05)$. The percentage of $\mathrm{CD}^{+} \mathrm{CD}^{+} \mathrm{T}$ cells was higher in the PCB-CIK than that in the TCB-CIK cells on day 14 ( $\mathrm{P}<0.05$, Fig. $2 \mathrm{f})$. However, the percentage of $\mathrm{CD} 3^{+} \mathrm{CD} 8^{+} \mathrm{T}$ cells did not differ in the CIK cells derived from preterm and term infant cord blood on days 0 and 7 ( $P>0.05)$.

Activated and inhibitory cell surface markers of CIK cells. We detected the cell surface markers by flow cytometry on days 0 and 14. We gated the population of $\mathrm{CD}^{+} \mathrm{CD}^{+}$or $\mathrm{CD}^{+} \mathrm{CD} 4^{+} \mathrm{T}$ 
a

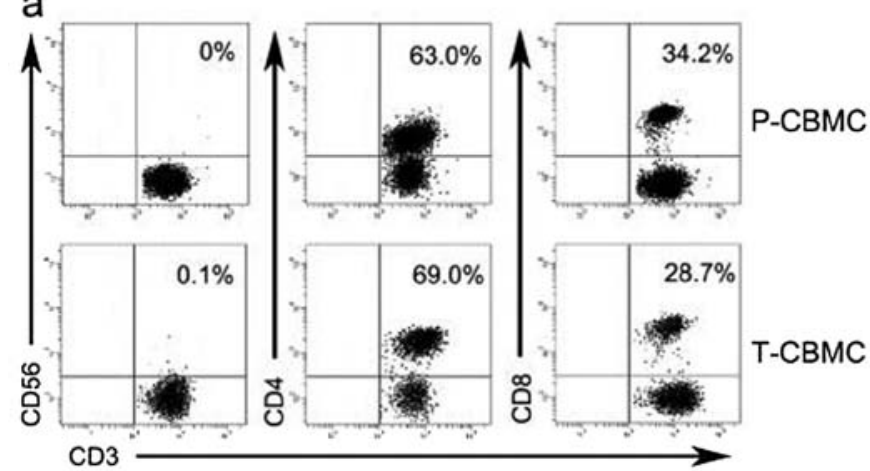

C
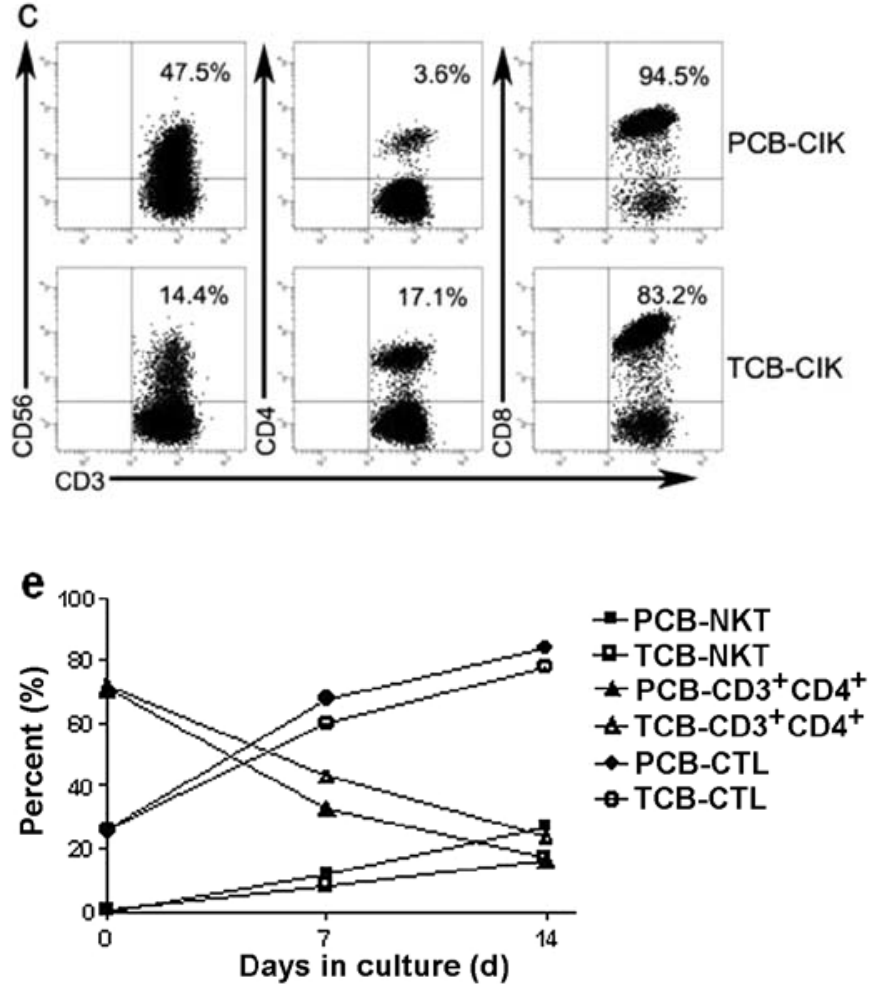

b

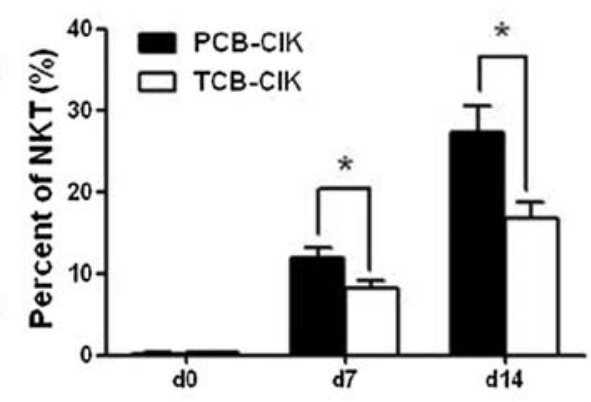

d
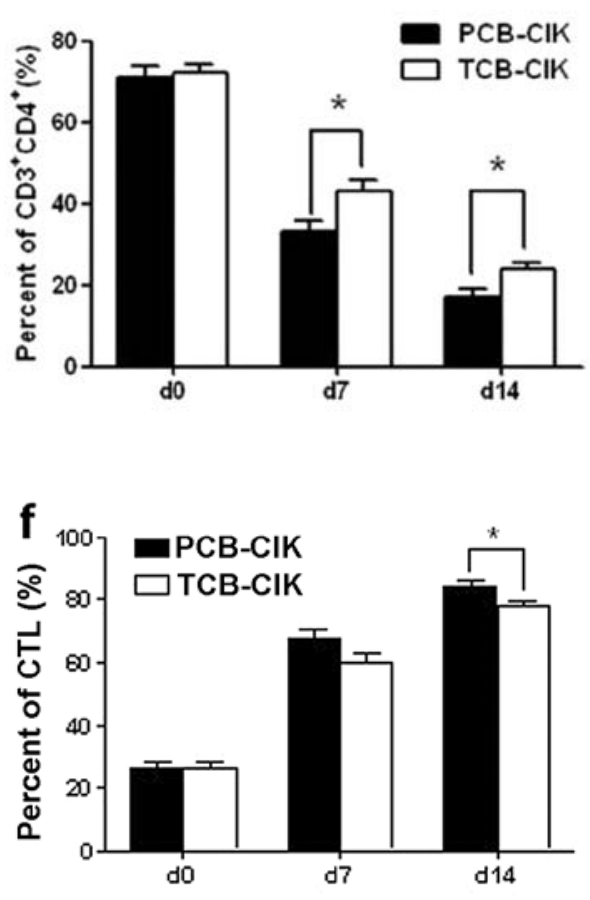

Figure 2. Immunophenotype analysis of cells from preterm and term infant cord blood. The percentages of $\mathrm{NKT}\left(\mathrm{CD} 3^{+} \mathrm{CD} 56^{+}\right), \mathrm{CD} 3^{+} \mathrm{CD} 4^{+}$, and $\mathrm{CTL}$ $\left(\mathrm{CD}^{+} \mathrm{CD}^{+}\right)$cells were detected by flow cytometry, and the results are expressed as means $\pm \mathrm{SD}$ ( $\left.\mathrm{n}=10\right)$. (a) Typical phenotype analysis of mononuclear cells derived from preterm and term infant cord blood (P-CBMC and T-CBMC). (b) Columns represent the percentage of NKT cells at different time points in the two cell groups $\left(\mathrm{n}=10,{ }^{*} \mathrm{P}<0.05\right)$. (c) Typical phenotype analysis of CIK cells from preterm and term infants (PCB-CIK and TCB-CIK). (d) Columns represent the percentage of $\mathrm{CD}^{+} \mathrm{CD}^{+} \mathrm{T}$ cells at different time points in the two cell groups $\left(\mathrm{n}=10,{ }^{*} \mathrm{P}<0.05\right)$. (e) Trend of NKT and CD3 ${ }^{+} \mathrm{CD} 4{ }^{+} \mathrm{T}$ cells and $\mathrm{CTL}$ percentages during culture in the two cell groups $(\mathrm{n}=10)$. (f) Columns represent the percentage of CTLs at different time points in the two cell groups ( $\left.\mathrm{n}=10,{ }^{*} \mathrm{P}<0.05\right)$. CIK, cytokine-induced killer; PCB, preterm infant cord blood; TCB, term infant cord blood.

cells, and analyzed the expression of CD27, CD28 and PD-1 in CBMCs and CIK cells (Fig. 3a, b and e). On day 0 , the proportions of activated $\mathrm{CD} 8{ }^{+} \mathrm{CD} 27^{+}(94.4 \pm 5.2$ vs. $86.5 \pm 6.8 \%$, $\mathrm{P}=0.004)$ and $\mathrm{CD}^{+} \mathrm{CD} 28^{+}(92.2 \pm 5.4$ vs. $82.5 \pm 8.9 \%, \mathrm{P}<0.05)$ $\mathrm{T}$ cells were higher in the $\mathrm{P}-\mathrm{CBMCs}$ than the proportions in the T-CBMCs, while the proportions of $\mathrm{CD} 8^{+} \mathrm{PD}-1^{+}, \mathrm{CD} 4^{+} \mathrm{CD} 27^{+}$, $\mathrm{CD} 4{ }^{+} \mathrm{CD} 28^{+}$and $\mathrm{CD} 4{ }^{+} \mathrm{PD}-1^{+} \mathrm{T}$ cells showed no significant differences between the P-CBMCs and the T-CBMCs $(\mathrm{P}>0.05$, Fig. 3c). On day 14, the proportion of activated $\mathrm{CD} 8^{+} \mathrm{CD} 27^{+}$ $\mathrm{T}$ cells was higher in the PCB-CIK than that in the TCB-CIK cells $(82.5 \pm 9.6$ vs. $71.5 \pm 9.2 \%, \mathrm{P}<0.05)$, while the proportions of $\mathrm{CD} 8^{+} \mathrm{PD}-1^{+}, \mathrm{CD} 8^{+} \mathrm{CD} 28^{+}, \mathrm{CD} 4^{+} \mathrm{CD} 27^{+}, \mathrm{CD} 4^{+} \mathrm{CD} 28^{+}$and CD $4^{+} \mathrm{PD}-1^{+} \mathrm{T}$ cells showed no significant differences between the PCB-CIK and TCB-CIK cells (P>0.05, Fig. 3d).
Cytokine production of CIK cells. We examined the production of IFN- $\gamma$, IL-10 and TNF- $\alpha$ in the two groups. On day 14, the supernatants were collected and assayed by ELISA to quantify the three cytokines. PCB-CIK cells produced more TNF- $\alpha(6 \pm 5.5 \mathrm{pg} / \mathrm{ml})$, yet the two groups had no statistical significance $(\mathrm{P}=0.19)$. However, the secretion of IL-10 was lower in the PCB-CIK cells $(10.2 \pm 6.8$ vs. $29.6 \pm 13.0 \mathrm{pg} / \mathrm{ml}$, $\mathrm{P}<0.01$, Fig. 4), while there was no difference in the secretion level of IFN- $\gamma(\mathrm{P}>0.05)$.

Expression of granzyme $B$ and perforin in the CIK cells. To investigate the expression of granzyme B and perforin, CIK cells were harvested on day 14 . We analyzed the expression of granzyme B and perforin by flow cytometry (Fig. 5a). 

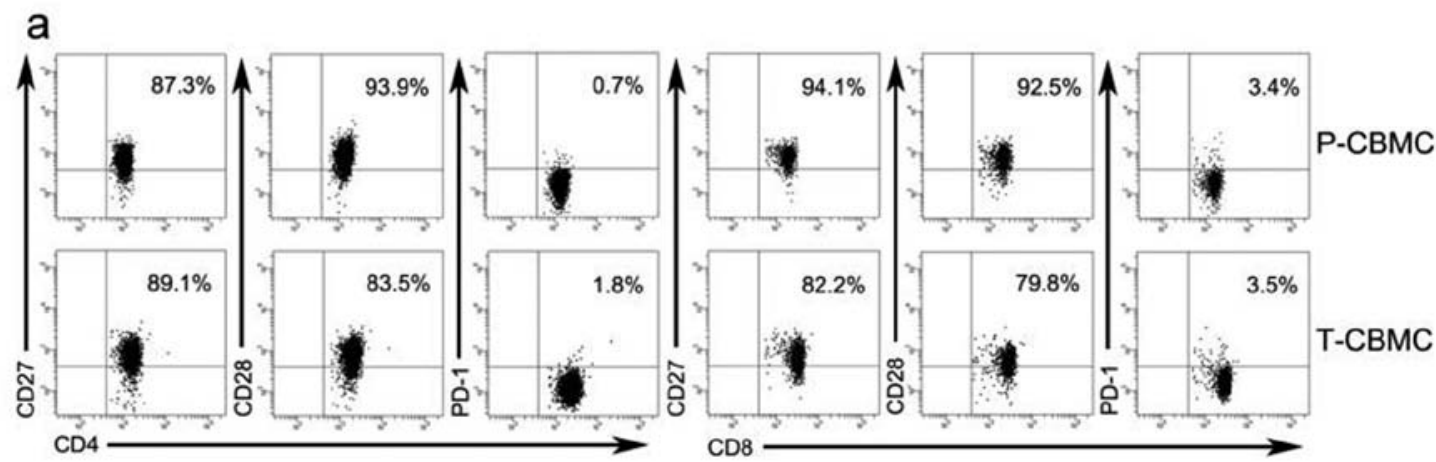

b
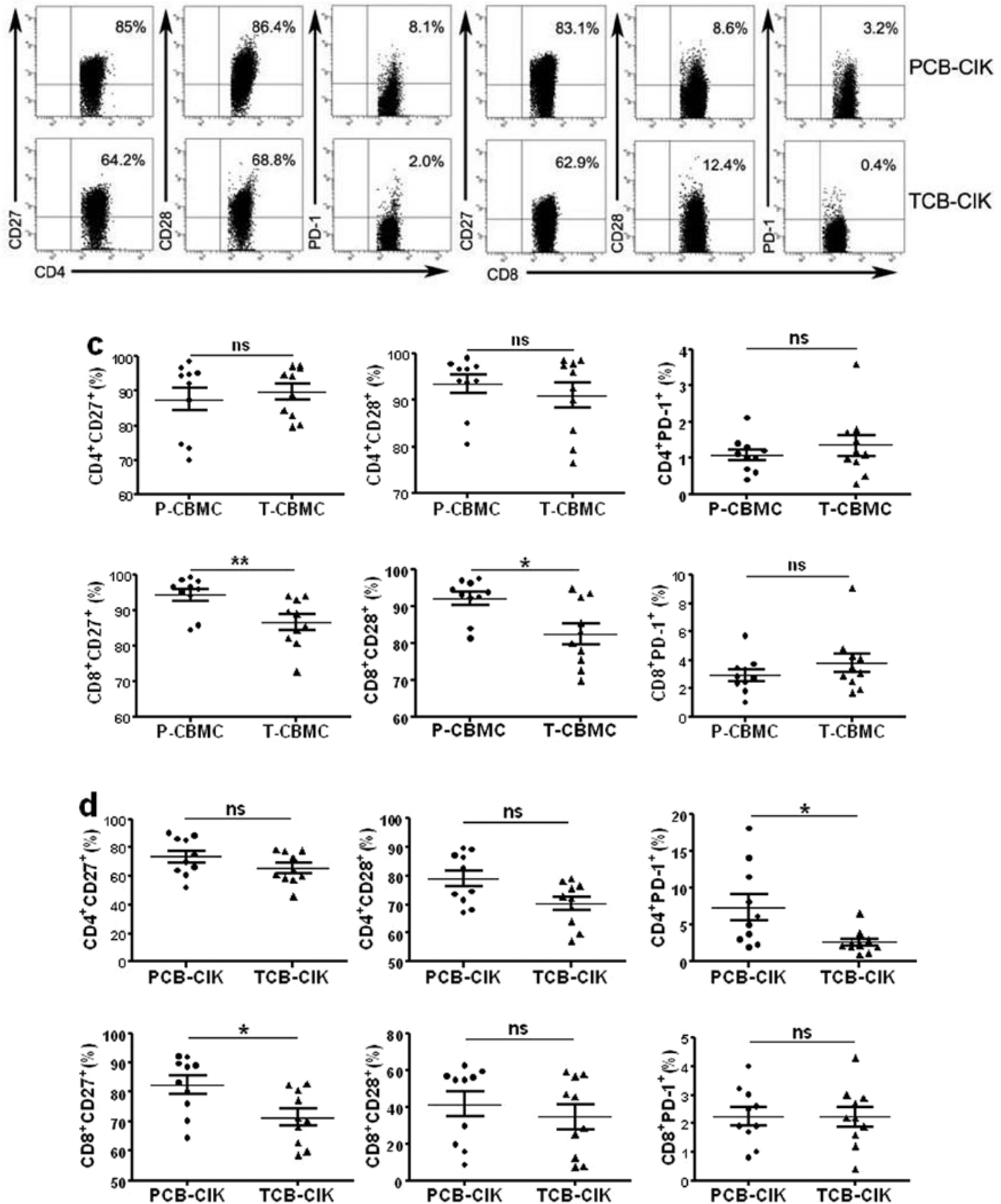

Figure 3. Expression of activated and inhibitory cell surface markers at different time points in the two cell groups. (a) Typical activated and inhibitory cell surface markers of mononuclear cells derived from preterm and term infant cord blood (P-CBMC and T-CBMC). (b) Typical activated and inhibitory cell surface markers of CIK cells derived from preterm and term infant cord blood (PCB-CIK and TCB-CIK). (c) Statistical analysis of cell surface markers in CD8 and CD4 T cells on day $0\left(n=10,{ }^{*} \mathrm{P}<0.05,{ }^{* *} \mathrm{P}<0.01\right)$. (d) Statistical analysis of cell surface markers in CD8 and CD4 T cells on day 14 ( $\left.\mathrm{n}=10,{ }^{*} \mathrm{P}<0.05\right)$. 

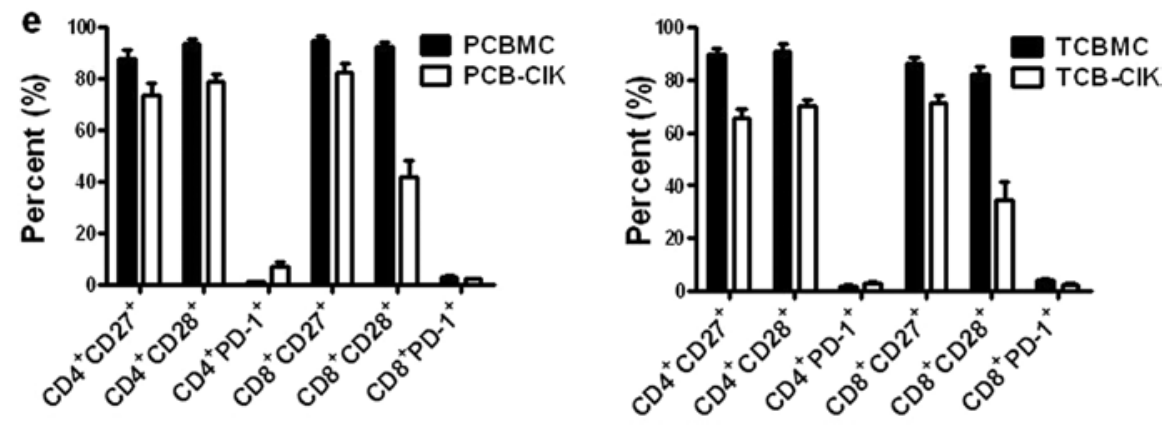

Figure 3. Continued. (e) Changes in activated and inhibitory cell surface markers at different time points (day 0 and 14) in the two cell groups. Columns represent the percentage of cell surface markers. CIK, cytokine-induced killer; PCB, preterm infant cord blood; TCB, term infant cord blood.
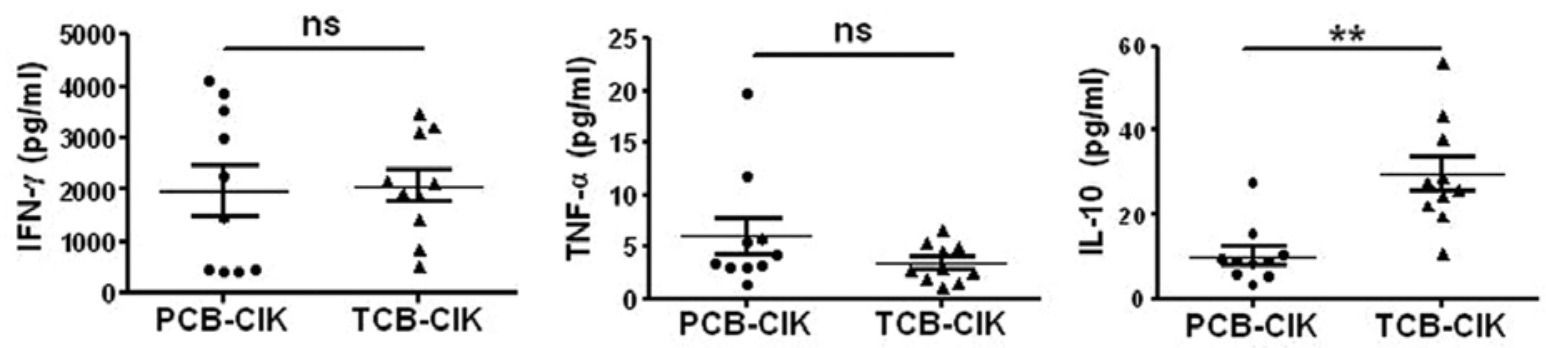

Figure 4. Secretion of cytokines in CIK cells $\left(\mathrm{n}=10,{ }^{*} \mathrm{P}<0.01\right)$. PCB-CIK, CIK cells derived from preterm infant cord blood; TCB-CIK, CIK cells derived from term infant cord blood.

a
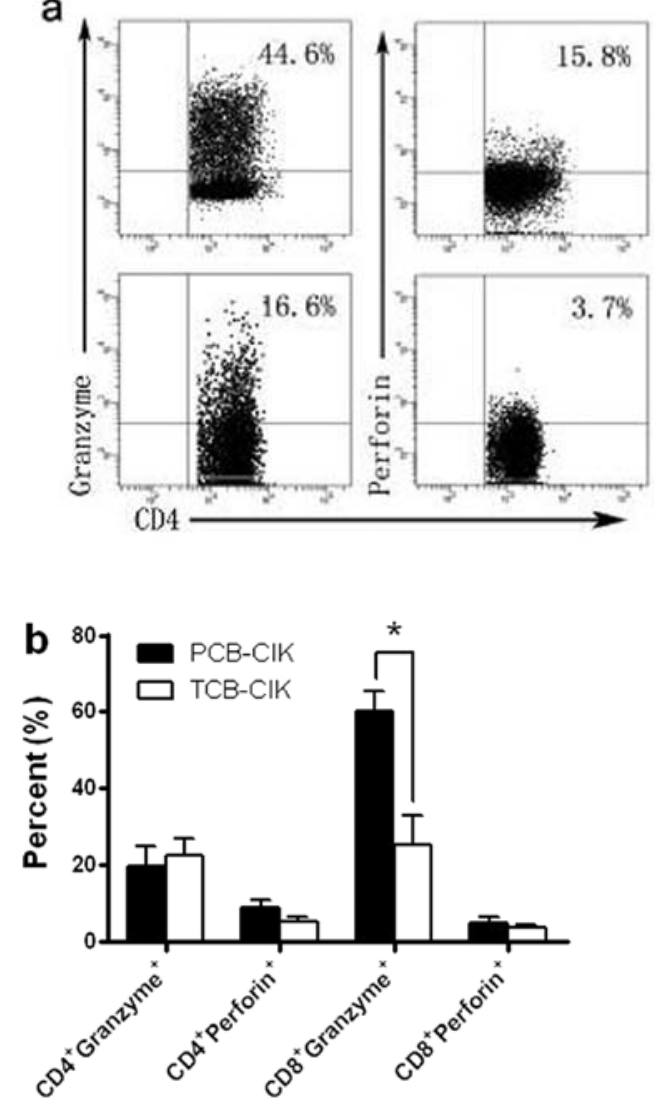

Figure 5. Expression of granzyme $\mathrm{B}$ and perforin in CIK cells $\left(\mathrm{n}=10,{ }^{*} \mathrm{P}<0.05\right)$ (a) The expression of granzyme Band perforin in CIK cells derived from preterm and term infant cord blood. (b) Columns represent the percentage of granzyme B and perforin in the two cell groups. CIK, cytokine-induced killer; PCB, preterm infant cord blood; TCB, term infant cord blood.

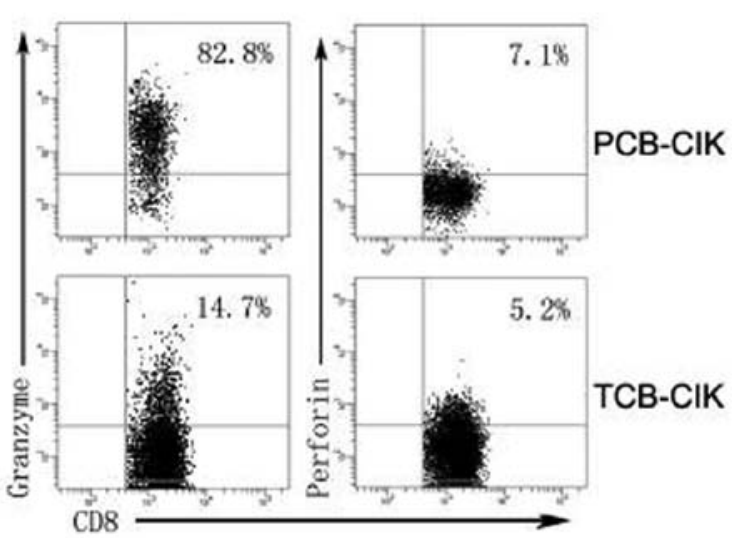

The percentage of $\mathrm{CD}^{+} \mathrm{CD}^{+}$granzyme $\mathrm{B}^{+}$was higher in the PCB-CIK than that in the TCB-CIK cells $(59.5 \pm 14.3$ vs. $25.2 \pm 20.5 \%, \mathrm{P}<0.05$, Fig. $5 \mathrm{~b}$ ). However, the percentages of $\mathrm{CD}^{+}{ }^{+} \mathrm{CD} 8^{+}$perforin ${ }^{+}, \mathrm{CD}^{+}{ }^{+} \mathrm{CD} 4^{+}$perforin ${ }^{+}$and $\mathrm{CD}^{+}{ }^{+} \mathrm{CD} 4^{+}$granzyme ${ }^{+}$had no difference between the PCB-CIK and TCB-CIK cells $(\mathrm{P}>0.05)$.

Cytotoxicity activity of CIK cells. CIK cells were co-cultured with logarithmic phase K562 cells at an effector-target ratio of 20:1. The proportion of activated CIK cells was identified by expression of CD107a, which is located in the cytoplasm and transported to the cell surface after activation-induced granule exocytosis (17). The percentage of $\mathrm{CD} 107 \mathrm{a}^{+}$cells exhibited no difference between the PCB-CIK and TCB-CIK cells (Fig. 6a and b, P>0.05). 
a
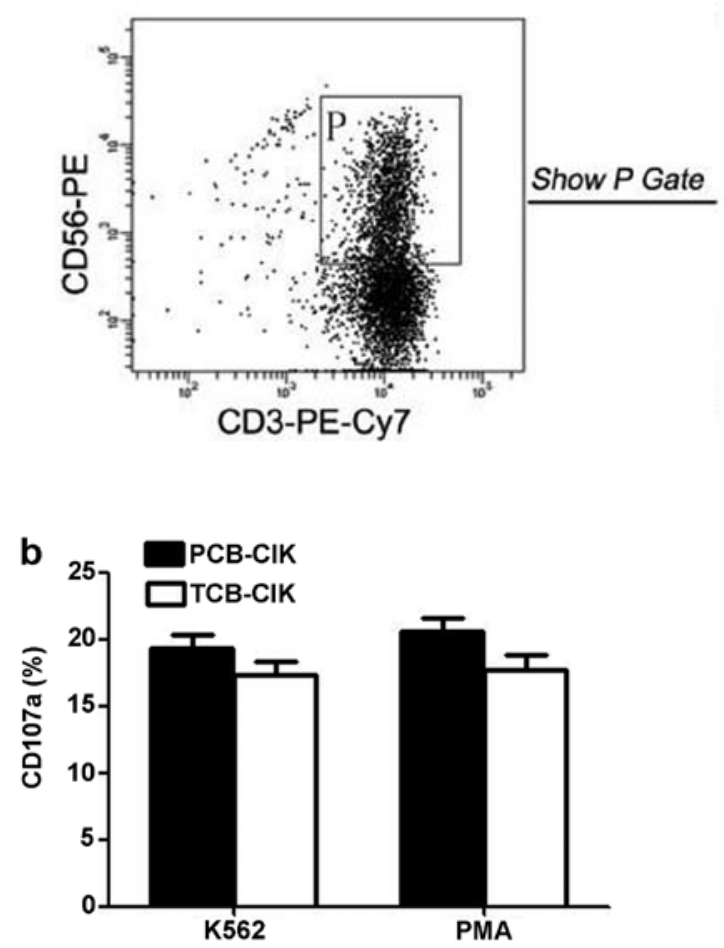

Figure 6. Cytotoxicity of CIK cells in vitro $\left(\mathrm{n}=10,{ }^{*} \mathrm{P}<0.05\right)$. (a) The expression of CD107a was detected by flow cytometry. (b) Columns represent the percentage of CD107a in the two cell groups. CIK, cytokine-induced killer; PCB, preterm infant cord blood; TCB, term infant cord blood.

\section{Discussion}

Adoptive cellular immunotherapy has been available for treating tumors for nearly 30 years. One of the first prototypes used was lymphokine-activated killer (LAK) cells. Subsequently, tumor-infiltrating lymphocytes (TILs), dendritic and CIK cells appeared in succession (18). CIK cells are a heterogeneous population with different cell phenotypes that are induced by incubation of mononuclear cells with various cytokines, such as IFN- $\gamma$, the anti-CD3 monoclonal antibody and IL-2 (4). As a new type of immune cell, CIK cells have higher proliferation and cytotoxicity than other immune cells. However, CIK cells that are used in preclinical or clinical study are mainly derived from peripheral blood and term infant cord blood. In recent years, the birth rate of preterm infants has significantly increased. To our knowledge, no other studies have been published on the comparison of PCB-CIK and TCB-CIK cells. Whether the biological characteristics and function are different between PCB-CIK and TCB-CIK cells is still unknown.

In the present study, we cultured PCB-CIK and TCB-CIK cells for 14 days, and analyzed the proliferation, phenotype and the expression of activated or inhibitory cell surface markers. We also detected the production of cytokines, the expression of granzyme B and perforin, and the cytotoxicity between the two cell groups. Unlike previously described (19), we cultured the CIK cells for 14 days, since Helms et al (12) revealed that short-term cultured CIK cells exhibit full cytotoxicity in vitro.

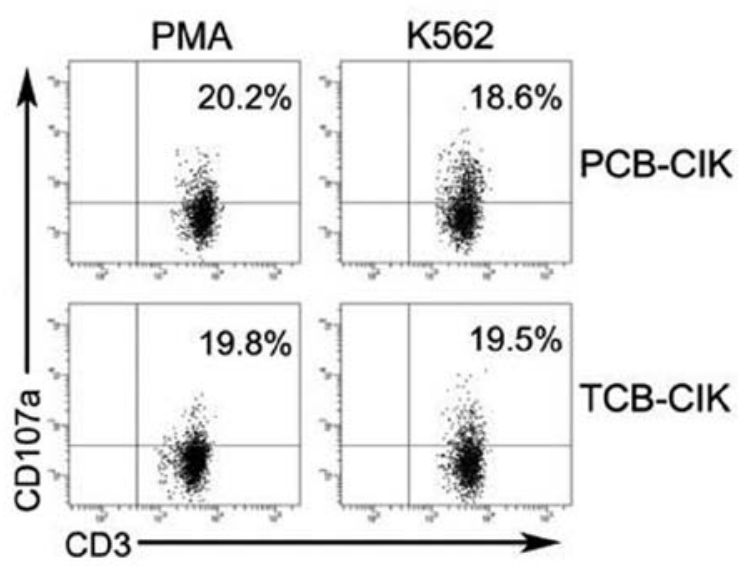

Furthermore, many preclinical and clinical studies have shown that CIK cells require 14 days of culture $(20,21)$.

The main limitation preventing the successful clinical translation of adoptive cellular immunotherapy strategies is the obtainment of sufficient numbers of antitumor immune effector cells. The results showed that PCB-CIK cells had a higher proliferation rate than the TCB-CIK cells on days 7, 8,9 and 10. The possible cause is that preterm infant cord blood has more immature and undifferentiated cells (22). However, the PCB-CIK cells were difficult to cultivate. On day 6, PCB-CIK cells had a trend of a low proliferation index, yet it was similar in the two groups. The probable cause is that PCB-CIK cells have poor adaptability. Kornacker et al (23) reported that CIK cells derived from peripheral blood have a long survival period and high ability for anti-apoptosis. Whether there exist differences in PCB-CIK and TCB-CIK cells is unknown. Thus, we must further explore the apoptosis of CIK cells from preterm and term infant cord blood.

CIK cells consist of $\mathrm{CD}^{+}{ }^{+} \mathrm{CD} 56^{+}$double positive and NK cells, and $\mathrm{CD}^{+}{ }^{+} \mathrm{CD} 56^{-} \mathrm{T}$ lymphocytes. The antitumor activity of CIK cells seems to be associated with the $\mathrm{CD}^{+} \mathrm{CD} 56^{+}$subset, which has an in vitro fold expansion that varies from a few to $>1,000$-fold (24). The reason for this variability is unclear, and additional strategies are currently under investigation to improve the expansion rates. In the present study, the content of $\mathrm{CD}^{+}{ }^{+} \mathrm{CD}^{2} 6^{+}$subsets of P-CBMCs and T-CBMCs was low, and there was no statistical difference between the two groups. However, the proportion of $\mathrm{CD}^{+} \mathrm{CD} 56^{+}$was higher in the PCB-CIK cells than that in the TCB-CIK cells on days 7 and 14. The percentage of NKT cells in the present study was different from the percentage found in previous research (25). It may be associated with the activity of cytokines and individual differences. The results demonstrate that PCB-CIK cells may be superior to TCB-CIK cells in cytotoxicity.

In recent years, a number of studies have reported the proliferation rate and immune phenotype of CB-CIK cells, yet few studies have investigated activation or inhibitory cell surface markers. In the present study, we detected the expression of $\mathrm{CD} 27, \mathrm{CD} 28$ and PD-1. CD27 is a transmembrane homodimer with subunits of $55 \mathrm{kDa}$, which was first detected and named in 1987 (26). Importantly, CD27 is a member of the TNF-receptor superfamily expressed on $\mathrm{T}$ cells that provide a costimulatory signal, which is required for generation, activation and differentiation of $\mathrm{T}$ cell immunity (27). CD28, 
which is expressed on the surface of $\mathrm{T}$ cells, is required for $\mathrm{T}$ cell activation. CD28 improves the in vivo expansion and persistence of CAR-modified T cells by providing costimulatory signals (28). The expression of CD28 and CD27 was higher in the PCB-CIK than that in the TCB-CIK cells. PD-1 is a member of the CD28/CTLA-4 superfamily. Studies have reported that $\mathrm{PD}-1$ and its ligands negatively regulate immune responses (29). In the present study, the expression of PD-1 showed no significant difference between the PCB-CIK and TCB-CIK cells. The results preliminary demonstrated that PCB-CIK cells had more potential to promote the proliferation and differentiation of T cells.

IFN- $\gamma$ is an important factor for antitumor activities, including the activation of CTLs and NK cells, the induction of chemokines that mediate T-cell infiltration into tumors, and the upregulation of MHC class I expression in tumor cells (30). TNF- $\alpha$, which consists of 157 amino acids, is secreted by activated lymophocytes and monocytes. TNF- $\alpha$ can enhance the antitumor ability of CIK cells (31). In the present study, the levels of IFN- $\gamma$ and TNF- $\alpha$ in PCB-CIK and TCB-CIK cells had no statistical significance. Yet there was a trend that PCB-CIK cells could produce more TNF- $\alpha$ than CB-CIK. The reason may be that the study had a small sample size. IL-10 is an inhibitory cytokine (32), which can suppress the secretion of IL-2 and IFN- $\gamma$. In this study, the secretion of IL-10 was lower in the PCB-CIK cells. The results indicate that the activity of PCB-CIK cells may not be lower than TCB-CIK cells.

We evaluated the expression of granzyme $\mathrm{B}$ and perforin in CIK cells. Granzyme B and perforin are required for the cytotoxicity of CIK cells (33). Perforin perforates the target cell membrane and forms a channel, and then water and electrolytes move inside the cells and subsequently wreak havoc. Granzyme B can induce the cellular apoptosis of target cells by activating the apoptosis-related enzyme system (34). The results suggest that the expression of granzyme $\mathrm{B}$ was higher in the PCB-CIK cells than that in the TCB-CIK cells. This directly demonstrate that PCB-CIK cells have more potential to kill tumors. We also detected the expression of CD107a, also known as lysosome-associated membrane protein 1 (LAMP1), which is a high glycosylation protein and a functional marker for the identification of natural killer cell activity (18). The expression of CD107a had no statistical significance between the two cell groups. The expression of CD107a was in line with the secretion of granzyme B and perforin, which is in accordance with previous research (35). The results demonstrate that PCB-CIK cells have the same antitumor function as TCB-CIK cells.

In conclusion, the present study suggests that PCB-CIK cells have a high proliferation rate and expression of activated cell surface markers in vitro. Furthermore, the cytotoxicity did not differ between the PCB-CIK and TCB-CIK cells. All of the results suggest that $\mathrm{PCB}-\mathrm{CIK}$ cells have the potential for clinical application. However, it is difficult to culture PCB-CIK cells, therefore further study is needed to explore the culture optimization conditions.

\section{Acknowledgements}

The authors gratefully thank the Key Laboratory of Clinical Medicine, First Affiliated Hospital of Zhengzhou University for providing facilities. The present study was supported by the Fund for Project of Newborn Disease, Key Laboratory of the Ministry of Health (1213).

\section{References}

1. Bear AS, Hanley PJ, Bosque DM, et al: Low rate of infusional toxicity after expanded cord blood transplantation. Cytotherapy 16: 1153-1157, 2014.

2. Humphries C: Adoptive cell therapy: honing that killer instinct. Nature 504: S13-S15, 2013.

3. Yee C: Adoptive T-cell therapy for cancer: boutique therapy or treatment modality? Clin Cancer Res 19: 4550-4552, 2013.

4. Restifo NP, Dudley ME and Rosenberg SA: Adoptive immunotherapy for cancer: harnessing the T cell response. Nat Rev Immunol 12: 269-281, 2012.

5. Schmidt-Wolf IG, Negrin RS, Kiem HP, et al: Use of a SCID mouse/human lymphoma model to evaluate cytokine-induced killer cells with potent antitumor cell activity. J Exp Med 174: 139-149, 1991.

6. Pievani A, Borleri G, Pende D, et al: Dual-functional capability of $\mathrm{CD}^{+} \mathrm{CD} 56^{+} \mathrm{CIK}$ cells, a T-cell subset that acquires NK function and retains TCR-mediated specific cytotoxicity. Blood 118: 3301-3310, 2011.

7. Liu L, Zhang W, Qi X, et al: Randomized study of autologous cytokine-induced killer cell immunotherapy in metastatic renal carcinoma. Clin Cancer Res 18: 1751-1759, 2012.

8. Gammaitoni L, Giraudo L, Leuci V, et al: Effective activity of cytokine-induced killer cells against autologous metastatic melanoma including cells with stemness features. Clin Cancer Res 19: 4347-4358, 2013.

9. Laport GG, Sheehan K, Baker J, et al: Adoptive immunotherapy with cytokine-induced killer cells for patients with relapsed hematologic malignancies after allogeneic hematopoietic cell transplantation. Biol Blood Marrow Transplant 17: 1679-1687, 2011.

10. Ma YJ, He M, Han JA, et al: A clinical study of HBsAg-activated dendritic cells and cytokine-induced killer cells during the treatment for chronic hepatitis B. Scand J Immunol 78: 387-393, 2013.

11. Mesiano G, Todorovic M, Gammaitoni L, et al: Cytokineinduced killer (CIK) cells as feasible and effective adoptive immunotherapy for the treatment of solid tumors. Expert Opin Biol Ther 12: 673-684, 2012.

12. Helms MW, Prescher JA, Cao YA, et al: IL-12 enhances efficacy and shortens enrichment time in cytokine-induced killer cell immunotherapy. Cancer Immunol Immunother 59: 1325-1334, 2010.

13. Chan JK, Hamilton CA, Cheung MK, et al: Enhanced killing of primary ovarian cancer by retargeting autologous cytokineinduced killer cells with bispecific antibodies: a preclinical study. Clin Cancer Res 12: 1859-1867, 2006.

14. Frumento G, Zheng Y, Aubert G, et al: Cord blood T cells retain early differentiation phenotype suitable for immunotherapy after TCR gene transfer to confer EBV specificity. Am J Transplant 13: 45-55, 2013.

15. Introna M, Pievani A, Borleri G, et al: Feasibility and safety of adoptive immunotherapy with CIK cells after cord blood transplantation. Biol Blood Marrow Transplant 16: 1603-1607, 2010.

16. Li J, Wang QH, Wu HM, et al: A survey of neonatal births in maternity departments in urban China in 2005. Zhongguo Dang Dai Er Ke Za Zhi 14: 7-10, 2012 (In Chinese).

17. Krzewski K, Gil-Krzewska A, Nguyen V, et al: LAMP1/CD107a is required for efficient perforin delivery to lytic granules and NK-cell cytotoxicity. Blood 121: 4672-4683, 2013.

18. Jiang J, Wu C and Lu B: Cytokine-induced killer cells promote antitumor immunity. J Transl Med 11: 83, 2013.

19. Durrieu L, Gregoire-Gauthier J, Dieng MM, et al: Human interferon- $\alpha$ increases the cytotoxic effect of $\mathrm{CD} 56^{+}$cord blood-derived cytokine-induced killer cells on human B-acute lymphoblastic leukemia cell lines. Cytotherapy 14: 1245-1257, 2012.

20. Li R, Wang C, Liu L, et al: Autologous cytokine-induced killer cell immunotherapy in lung cancer: a phase II clinical study. Cancer Immunol Immunother 61: 2125-2133, 2012. 
21. Yang L, Ren B, Li H, et al: Enhanced antitumor effects of DC-activated CIKs to chemotherapy treatment in a single cohort of advanced non-small-cell lung cancer patients. Cancer Immunol Immunother 62: 65-73, 2013.

22. D'Alessio F, Mirabelli P, Gorrese M, et al: Polychromatic flow cytometry analysis of $\mathrm{CD}^{2} 4^{+}$hematopoietic stem cells in cryopreserved early preterm human cord blood samples. Cytometry A 79: 14-24, 2011

23. Kornacker M, Moldenhauer G,Herbst M, et al: Cytokine-induced killer cells against autologous CLL: direct cytotoxic effects and induction of immune accessory molecules by interferon- $\gamma$. Int J Cancer 119: 1377-1382, 2006.

24. Zanon C, Stocchero M, Albiero E, et al: Multivariate statistical data analysis as a tool to analyze ex vivo expansion dynamics of cytokine-induced killer cells. Cytometry B Clin Cytom 86: 257-262, 2014

25. Niu Q, Wang W, Li Y, et al: Cord blood-derived cytokineinduced killer cells biotherapy combined with second-line chemotherapy in the treatment of advanced solid malignancies. Int Immunopharmacol 11: 449-456, 2011.

26. van Lier RA, Borst J, Vroom TM, et al: Tissue distribution and biochemical and functional properties of Tp55 (CD27), a novel T cell differentiation antigen. J Immunol 139: 1589-1596, 1987.

27. Taraban VY, Rowley TF, Kerr JP, et al: CD27 costimulation contributes substantially to the expansion of functional memory $\mathrm{CD}^{+} \mathrm{T}$ cells after peptide immunization. Eur J Immunol 43: 3314-3323, 2013.

28. Pufnock JS, Cigal M, Rolczynski LS, et al: Priming CD8 ${ }^{+}$T cells with dendritic cells matured using TLR4 and TLR7/8 ligands together enhances generation of $\mathrm{CD}^{+} \mathrm{T}$ cells retaining $\mathrm{CD} 28$ Blood 117: 6542-6551, 2011.
29. Prosser ME, Brown CE, Shami AF, et al: Tumor PD-L1 co-stimulates primary human $\mathrm{CD} 8^{+}$cytotoxic $\mathrm{T}$ cells modified to express a PD1:CD28 chimeric receptor. Mol Immunol 51: 263-272, 2012.

30. Saga K, Tamai K, Yamazaki T, et al: Systemic administration of a novel immune-stimulatory pseudovirion suppresses lung metastatic melanoma by regionally enhancing IFN- $\gamma$ production. Clin Cancer Res 19: 668-679, 2013.

31. Wang Y, Bo J, Dai HR, et al: CIK cells from recurrent or refractory AML patients can be efficiently expanded in vitro and used for reduction of leukemic blasts in vivo. Exp Hematol 41: 241-252, 2013.

32. Wang YF, Kunda PE, Lin JW, et al: Cytokine-induced killer cells co-cultured with complete tumor antigen-loaded dendritic cells, have enhanced selective cytotoxicity on carboplatin-resistant retinoblastoma cells. Oncol Rep 29: 1841-1850, 2013.

33. Introna M, Franceschetti M, Ciocca A, et al: Rapid and massive expansion of cord blood-derived cytokine-induced killer cells: an innovative proposal for the treatment of leukemia relapse after cord blood transplantation. Bone Marrow Transplant 38: 621-627, 2006.

34. Kim TD, Lee SU, Yun S, et al: Human microRNA-27a* targets Prf1 and GzmB expression to regulate NK-cell cytotoxicity. Blood 118: 5476-5486, 2011.

35. Alter G, Malenfant JM and Altfeld M: CD107a as a functional marker for the identification of natural killer cell activity. J Immunol Methods 294: 15-22, 2004. 